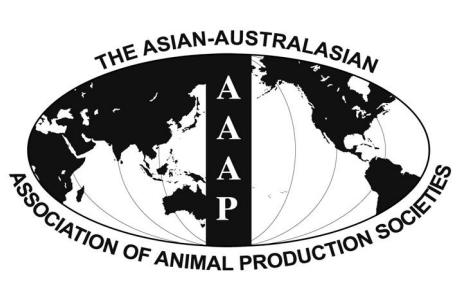

Open Access

Asian Australas. J. Anim. Sci.

Vol. 29, No. 2 : 263-270 February 2016

http://dx.doi.org/10.5713/ajas.15.0129

www.ajas.info

pISSN 1011-2367 elSSN 1976-5517

\title{
Effect of the Ratio of Raw Material Components on the Physico-chemical Characteristics of Emulsion-type Pork Sausages
}

\author{
Sang-Keun Jin ${ }^{1,2}$, So-Ra Ha ${ }^{1}$, Sun-Jin Hur ${ }^{3, *}$, and Jung-Seok Choi ${ }^{2, *}$ \\ ${ }^{1}$ Department of Animal Resources Technology, \\ Gyeongnam National University of Science and Technology, Jinju 660-758, Korea
}

\begin{abstract}
This study was conducted to investigate the effects of raw material ratio on the physicochemical characteristics of emulsion-type pork sausages. Experiment design was divided into 12 treatments, based on protein level (P), fat level (3P, 3.5P, and 4P), and water level $(4 \mathrm{P}+10,4 \mathrm{P}+15,4 \mathrm{P}+20$, and $4 \mathrm{P}+25)$. The $\mathrm{pH}$ and shear force values were significantly higher in $\mathrm{T} 7(3.5 \mathrm{P}$ fat and $4 \mathrm{P}+20$ water) than those of other treatments. The lightness and redness were greatly reduced by increasing the quantity of water. The treatments containing $3 \mathrm{P}$ fat and $4 \mathrm{P}+20$ water had the highest values of cohesiveness, springiness, gumminess, and chewiness. On the whole, when the protein $(\mathrm{P})$ and fat $(3 \mathrm{P}, 3.5 \mathrm{P}, 4 \mathrm{P})$ levels were fixed, an increase over the appropriate moisture level deteriorated many physicochemical characteristics. (Key Words: Emulsion-type Pork Sausage, Raw Material Components, Formulation, Physicochemical Characteristics, Water content)
\end{abstract}

\section{INTRODUCTION}

Emulsification technology has been used over several hundred years for the preparation of emulsion-type meat products. Emulsified meat products such as Frankfurt sausages are generally consumed in most of the countries. They tend to be more popular than other processed meat products, because they are convenient and are utilized in a variety of foods (Allais, 2010). One of the most important quality characteristics for processed meat products such as emulsified sausages is emulsion stability between fat and water contents. Fat is one of the most variable raw materials in emulsified meat products, as it plays an important role in the formation of meat emulsions with other ingredients, and

\footnotetext{
* Corresponding Authors: Sun-Jin Hur. Tel: +82-31-670-3084, Fax: +82-31-675-1381, E-mail: hursj@cau.ac.kr / Jung-Seok Choi. Tel: +82-55-751-3283, Fax: +82-55-751-3689, E-mail: choijs@gntech.ac.kr

${ }^{2}$ Swine Science and Technology Center, Gyeongnam National University of Science and Technology, Jinju 660-758, Korea.

${ }^{3}$ Department of Animal Science and Technology, Chung-Ang University, Anseong 456-756, Korea.

Submitted Feb. 12, 2015; Revised Apr. 16, 2015; Accepted Jun. 26, 2015
}

is related to flavor intensity, juiciness, and tenderness in sausage products (Hughes et al., 1997). Protein is also an important material for binding both the fat and water constituents in the meat emulsion. For example, soluble myofibrillar proteins are extracted by salt surrounding the fat particle, and they subsequently form the emulsion matrix with water and fat (Youssef and Barbut, 2010). The protein myosin is considered to be the most important emulsifier for water and fat in processed meat products (Galluzzo and Regenstein, 1978). Another major component of the meat emulsion is water. In the emulsion, water performs a number of functions such as: i) functioning as a curing solution; ii) regulating the temperature of the batter; iii) saving on production costs; and iv) having an impact on the texture and juiciness of the product (Ockerman and Basu, 2004). Traditionally, the formulation of sausage products was carried out by experts, who based their processes and formulations on years of experience in the trade, in order to obtain the desired quality characteristics of the sausages (Pouttu and Puolanne, 2004). However, in an attempt to make a greater capital profit, sausages are now often produced to minimize yield losses at the minimum cost, and this can be achieved by implementing formulaic recipes in 
the production processing line. In the late 1950 s, a few ingenious operators began to calculate least cost formulations (LCF) using linear programming with highspeed computers (Pearson and Gillett, 1996). The LCF program allows the user to restrict attributes such as cost, ingredients, composition, and capacity of the final products before the manufacture of the processed meat products. Therefore, with the implementation of linear programming, the quality properties of meat emulsions can be estimated based on their chemical composition, including their water, protein, and fat contents (Pouttu and Puolanne, 2004). In addition, there are a number of factors that affect the binding ability between meat protein, fat, and water. In particular, a number of studies regarding the processing technology of emulsion-type sausages have been published, including research into additives, substitutes, chopping temperature, pressure, mixing time, and processing procedure (Colmenero et al., 1996; Banon et al., 2008; Wang et al., 2009). However, although the raw material components have a big impact on emulsion-type sausages, very few studies have been conducted using the LCF program to assess the physicochemical characteristics based on the ratio of raw materials. Therefore, the objective of this study was to investigate the effect of the ratio of the raw material components on physicochemical characteristics in emulsion-type pork sausages, and to determine the optimized ratios of these raw material components for sausage production.

\section{MATERIALS AND METHODS}

\section{Sample preparation}

Approximately $44 \mathrm{~kg}$ of fresh lean pork and back fat was purchased from a local meat packaging plant, and visible fat and connective tissues were removed. All trimmed pork and back fat was ground twice through a
$9 \mathrm{~mm}$ plate in a grinder (MGB-32, Hankook Fujee Industries Co. Ltd., Suwon, Korea). The experimental design (Table 1) used for the processing test of emulsiontype pork sausage was derived from the component percentages of raw materials. The ratios of the raw material components were calculated using the LCF program (Lingo 14.0, Lindo systems Inc., Chicago, IL, USA) based on the sausage processing experience of Jin et al. (2008). For example, if the formula corresponding to Treatment 1 $($ protein[P]:fat:water $)=(\mathrm{P}: 3 \mathrm{P}: 4 \mathrm{P}+10)$ is used, the equation for the sausage processing formula in the LCF program is as follows:

$$
\begin{aligned}
& \mathrm{X}_{1}=\text { Pork }(20 \% \text { Protein }+5 \% \text { Fat }+75 \% \text { Moisture }) \\
& \mathrm{X}_{2}=\text { Back fat }(82 \% \text { Fat }+18 \% \text { Moisture }) \\
& \mathrm{X}_{3}=\text { Ice }(100 \% \text { Moisture }) \\
& \mathrm{X}_{4}=\text { Additives, } \\
& 0.05 \times \mathrm{X}_{1}+0.82 \times \mathrm{X}_{2}<=0.2 \times \mathrm{X}_{1} \times 3 \\
& 0.75 \times \mathrm{X}_{1}+0.18 \times \mathrm{X}_{2}+\mathrm{X}_{3}<=4 \times\left(0.2 \times \mathrm{X}_{1}\right)+10 \\
& \mathrm{X}_{4}=3.9 \\
& \mathrm{X}_{1}+\mathrm{X}_{2}+\mathrm{X}_{3}+\mathrm{X}_{4}=100
\end{aligned}
$$

The contents of the raw materials would thus be as follows: $53.82 \%$ pork, $36.09 \%$ back fat, $6.19 \%$ ice, and $3.9 \%$ additives. All treatments were calculated using this method. Raw materials, including pork, back fat, and ice, were mixed with additives (sodium chloride:sodium nitrite $=99: 1)$ according to the quantities outlined in Table 1 for treatments 1 to 12 (Silent cutter, Hankook Fujee Industries Co. Ltd., Hwasung, Korea), in order to compare

\begin{tabular}{|c|c|c|c|c|c|c|c|c|c|c|c|}
\hline Treatment & Protein & Fat & Moisture & Protein & Fat & Moisture & Pork & Back fat & Ice & $\begin{array}{l}\text { Additives } \\
\text { (N1) }\end{array}$ & Total \\
\hline $\mathrm{T} 1$ & $P$ & $3 \mathrm{P}$ & $4 \mathrm{P}+10$ & 10.76 & 32.28 & 53.05 & 53.82 & 36.09 & 6.19 & 3.90 & 100 \\
\hline $\mathrm{T} 2$ & $\mathrm{P}$ & $3 \mathrm{P}$ & $4 P+15$ & 10.14 & 30.41 & 55.55 & 50.69 & 34.00 & 11.41 & 3.90 & 100 \\
\hline $\mathrm{T} 3$ & $\mathrm{P}$ & $3 \mathrm{P}$ & $4 \mathrm{P}+20$ & 9.51 & 28.54 & 58.05 & 47.56 & 31.90 & 16.64 & 3.90 & 100 \\
\hline $\mathrm{T} 4$ & $\mathrm{P}$ & $3 \mathrm{P}$ & $4 P+25$ & 8.89 & 26.67 & 60.56 & 44.44 & 29.81 & 21.86 & 3.90 & 100 \\
\hline T5 & $\mathrm{P}$ & $3.5 \mathrm{P}$ & $4 \mathrm{P}+10$ & 10.13 & 35.46 & 50.52 & 50.65 & 40.15 & 5.31 & 3.90 & 100 \\
\hline T6 & $\mathrm{P}$ & $3.5 \mathrm{P}$ & $4 P+15$ & 9.54 & 33.40 & 53.17 & 47.71 & 37.82 & 10.58 & 3.90 & 100 \\
\hline $\mathrm{T} 7$ & $\mathrm{P}$ & $3.5 \mathrm{P}$ & $4 P+20$ & 8.95 & 31.33 & 55.81 & 44.77 & 35.48 & 15.85 & 3.90 & 100 \\
\hline $\mathrm{T} 8$ & $\mathrm{P}$ & $3.5 \mathrm{P}$ & $4 P+25$ & 8.36 & 29.27 & 58.45 & 41.83 & 33.15 & 21.12 & 3.90 & 100 \\
\hline T9 & $\mathrm{P}$ & $4 \mathrm{P}$ & $4 \mathrm{P}+10$ & 9.57 & 38.27 & 48.27 & 47.83 & 43.75 & 4.52 & 3.90 & 100 \\
\hline $\mathrm{T} 10$ & $\mathrm{P}$ & $4 \mathrm{P}$ & $4 P+15$ & 9.01 & 36.05 & 51.04 & 45.06 & 41.21 & 9.83 & 3.90 & 100 \\
\hline T11 & $\mathrm{P}$ & $4 \mathrm{P}$ & $4 P+20$ & 8.46 & 33.82 & 53.82 & 42.28 & 38.67 & 15.15 & 3.90 & 100 \\
\hline T12 & $\mathrm{P}$ & $4 \mathrm{P}$ & $4 P+25$ & 7.90 & 31.60 & 56.60 & 39.50 & 36.13 & 20.47 & 3.90 & 100 \\
\hline
\end{tabular}
the calculated formulas of emulsion-type pork sausages. The resulting emulsified meat batters were stuffed (E-25, Hankook Fujee Industries Co. Ltd., Suwon, Korea) into fibrous casings $(3 \mathrm{~cm}$ diameter) and cooked in a smoke house (programed at $54.4^{\circ} \mathrm{C}$ for $30 \mathrm{~min}$, then $65.6^{\circ} \mathrm{C}$ for 30 min, then $82.2^{\circ} \mathrm{C}$, and held until the internal temperature of

Table 1. Experimental design of emulsion-type pork sausages by ratio of raw material components (\%)

Protein contents (P) are fixed, fat contents (3P, 3.5P and 4P) are 3-4 times the protein content, moisture contents $(4 \mathrm{P}+10,4 \mathrm{P}+15,4 \mathrm{P}+20,4 \mathrm{P}+25)$ are 4 times the protein content $+10-25$, respectively.

Additives contain salt and nitrite (99:1). 
the sausages reached $72^{\circ} \mathrm{C}$ ). After cooling in an ice/water bath for $20 \mathrm{~min}$, each sausage was subsequently packed and covered with a polyvinyl chloride film (Krehalon UK Ltd., East Riding, Yorkshire, UK), and subjected to physicochemical analysis. Figure 1 shows the processing procedure for the production of emulsion-type pork sausages.

\section{pH}

The $\mathrm{pH}$ values were measured using a digital $\mathrm{pH}$ meter (SevenEasy pH, Mettler-Toledo AG, Schwerzenbach, Switzerland). The $\mathrm{pH}$ meter was calibrated daily with standard buffer solutions at $\mathrm{pH} 4.0$ and $\mathrm{pH} 7.0$ at $25^{\circ} \mathrm{C}$. The sample $(10 \mathrm{~g})$ was cut into small pieces and distilled water added $90 \mathrm{~mL}$. A homogenizer (T25B, IKA Sdn, Bhd., Selangor, Malaysia) was then used to form a slurry, and the $\mathrm{pH}$ recorded using the digital $\mathrm{pH}$ meter.

\section{Purge loss (\%)}

The purge loss was measured using the modified method of Carballo et al. (1995). After the sausage was

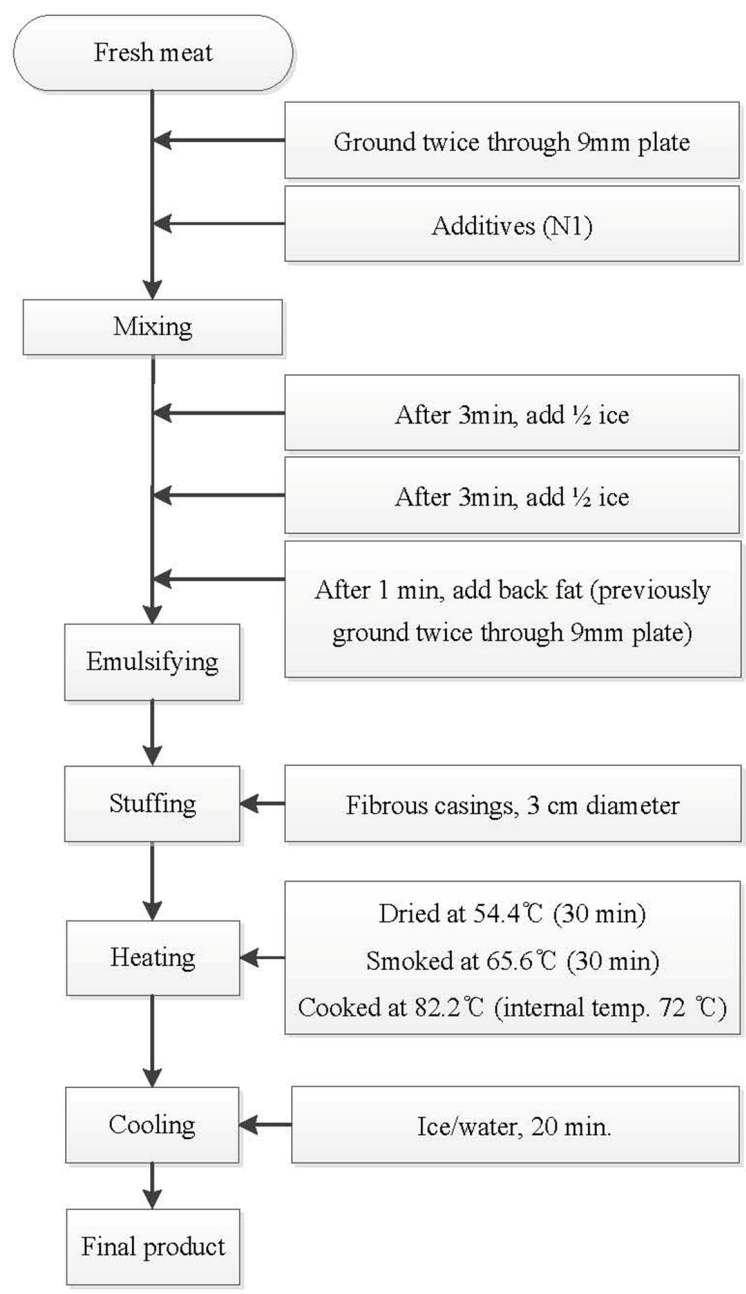

Figure 1. Processing procedure for emulsion-type pork sausages. weighed, it was stored in a refrigerator for $7 \mathrm{~d}$ at $10^{\circ} \mathrm{C}$. The sausage was then removed from the refrigerator, removed from its package, and blotted with Kimwipes (YuhanKimberly, Seoul, Korea) to eliminate any liquid from the surface of the sample. The weight of the sausage was then recorded one more, and the purge loss calculated as a weight percentage.

\section{Residual nitrite content (ppm)}

The residual nitrite content in the sausage was measured by diazotization. The absorbance of a pre-treated sample was measured with a Spectrophotometer (UV-2600, Shimadzu, Kyoto, Japan) at $540 \mathrm{~nm}$, and the concentration of nitrite calculated using the following equation:

$$
\mathrm{NO}_{2}(\mathrm{mg} / \mathrm{kg})=\frac{\mathrm{A}-\mathrm{As}}{\mathrm{S}} \times \mathrm{D}
$$
A, absorbance of sample
As, absorbance of standard
$\mathrm{S}$, sample weight
$\mathrm{D}$, dilution rate

\section{Color}

The color of the sausages was measured and quantified as $\mathrm{L}^{*}, \mathrm{a}^{*}$, and $\mathrm{b}^{*}$ values, using a colorimeter (Minolta Chroma Meter CR-300, Minolta Co., Ltd., Tokyo, Japan), which was calibrated with a white standard plate $(\mathrm{Y}=92.8$, $\mathrm{x}=0.3134$, and $\mathrm{y}=0.3193$ ). The sausages were cut into slices of $3 \mathrm{~cm}$ length, the surface color measured in triplicate, and mean values calculated for each sample.

\section{Analysis of texture properties}

The shear force of the sausages was estimated using an Instron 3343 (US/MX50, A\&D Co., Norwood, MA, USA) attached to a Warner Bratzler shearing device, providing a $100 \mathrm{~mm} / \mathrm{min}$ crosshead speed. Five cores $(2 \times 2 \times 1 \mathrm{~cm})$ of each sausage were analyzed at room temperature, with a crosshead speed of $100 \mathrm{~mm} / \mathrm{min}$. The average shear force value was calculated for each treatment and was expressed in $\mathrm{N} / \mathrm{cm}^{2}$. The textural properties of the sausages were analyzed using the EZ Test-500N texture analyzer (TAXTZ-5, Shimadzu Co., Japan) attached to a cylindrical plunger $(5 \mathrm{~mm}$ diameter, depression speed $=60 \mathrm{~mm} / \mathrm{min}$ ) and a $500 \mathrm{~N}$ load cell. Texture profile parameters that were measured included hardness, surface hardness, cohesiveness, springiness, gumminess, chewiness, and adhesiveness.

\section{Statistical analysis}

The entire experiment was replicated three times at different times in the same place, and a completely randomized design was used. The data physico-chemical properties of sausages were analyzed by analysis of 
variance using the general linear model procedure of SAS (SAS Institute, 2012). Duncan's multiple range test was used to determine the statistical significance among the mean values (SAS Institute, 2012) at a $95 \%$ significance level. All data analysis was performed using SAS for Windows, version 9.1.3 (SAS Institute Inc., Cary, NC, 2012). Analysis of Pearson's correlation test was carried out using SAS 9.1.3 program.

\section{RESULTS AND DISCUSSION}

\section{Composition of raw material components}

The composition of raw material components of the emulsion-type pork sausages as calculated by the Lingo 14.0 program was expressed in Table 1. Protein contents varied from $8.36 \%$ to $10.76 \%$, fat contents from $26.67 \%$ to $38.27 \%$, and water contents from $48.27 \%$ to $60.56 \%$. Consequently, protein and water contents reduced with increasing fat levels, while protein and fat contents reduced with an increase in water content. Colmenero et al. (1996) reported the comparison of chemical compositions between low-fat and high-fat products. The low-fat products were found to be composed of $73.2 \%$ water, $14.5 \%$ protein, and $8.5 \%$ fat, whereas the high-fat products were composed of $58.6 \%$ water, $14.0 \%$ protein, and $23 \%$ fat. In addition, Carrapiso (2007) manufactured sausages of different fat levels, where the formulation of the sausage with $15 \%$ fat was $48 \%$ pork shoulder, $33 \%$ belly, and $1.1 \%$ water, whereas the formulation of the sausage with only $5 \%$ fat was $72 \%$ pork shoulder, and $9.6 \%$ water. Hwang and Rhee (2003) also investigated the chemical composition of raw materials for the production of sausages. Lean pork was found to comprise of $70.8 \%$ water, $20.5 \%$ protein, and $7.5 \%$ fat, whereas lard was composed of $15.2 \%$ water, $6.7 \%$ protein, and $77.6 \%$ fat. As the costs to produce meat products are mainly decided by the prices of raw meat and additives, an increase in the added water could therefore reduce the cost of production, as water is free in many countries for such processes. Therefore, the development of a method for the manufacture of sausages that portray good quality physicochemical characteristics, form emulsions between protein and fat, and contain a high water content is advantageous to meat product producers.

\section{Quality characteristics}

The effects of variation in the ratio of the raw material components on the quality characteristics of emulsion-type pork sausages are shown in Table 2. Although some variation in $\mathrm{pH}$ was observed with variation of the raw material component ratios, the $\mathrm{pH}$ values were found to be generally independent of this. It was found that the $\mathrm{pH}$ values of treatments containing $3 \mathrm{P}$ fat $(\mathrm{T} 1, \mathrm{~T} 2, \mathrm{~T} 3$, and $\mathrm{T} 4)$ did not significantly differ. In the $\mathrm{pH}$ values of the treatments containing $3.5 \mathrm{P}$ fat (T5, T6, T7, and T8), T7 exhibited the highest value than the others. Also, the treatments containing $4 \mathrm{P}$ fat $(\mathrm{T} 9, \mathrm{~T} 10, \mathrm{~T} 11$, and $\mathrm{T} 12)$ did not show significant difference in $\mathrm{pH}$ values except for $\mathrm{T} 12$. In Pearson's correlation test on emulsion-type pork sausages based on raw material components, we observed that the variation of protein, fat, and water contents did not produce significant changes in the $\mathrm{pH}$ (Table 5). However, these results such as significantly higher $\mathrm{pH}$ values (T7 and T12) may have been influenced by experimental error. In general, the $\mathrm{pH}$ value of the meat product is dependent on the raw meat itself and on the additives, and this can subsequently affect the storage and quality characteristics of the product, including water holding capacity, freshness, meat color, texture, and binding capacity in meat products (Puolanne et al., 2001). While Pietrasik (1999) reported that the relative ratios of the various components did affect the $\mathrm{pH}$ of cooked products to some extent, small increases in $\mathrm{pH}$ were observed only with increasing fat content. In addition, variations in fat and moisture content did not appear to have any effect on the $\mathrm{pH}$ of bologna sausage (Carballo et al.,

Table 2. Quality characteristics of mulsion-type pork sausages by ratio of raw material components

\begin{tabular}{|c|c|c|c|c|}
\hline Treatment $^{1}$ & $\mathrm{pH}$ & Shear force $\left(\mathrm{N} / \mathrm{cm}^{2}\right)$ & Purge loss $(\%)$ & Nitrite (ppm) \\
\hline $\mathrm{T} 1$ & $6.17 \pm 0.01^{\mathrm{e}}$ & $11.46 \pm 0.29^{\mathrm{bc}}$ & $0.38 \pm 0.10^{\mathrm{d}}$ & $0.45 \pm 0.09^{\mathrm{abc}}$ \\
\hline $\mathrm{T} 2$ & $6.16 \pm 0.01^{\mathrm{e}}$ & $10.78 \pm 0.58^{\text {cde }}$ & $0.69 \pm 0.13^{\mathrm{bc}}$ & $0.47 \pm 0.01^{\mathrm{abc}}$ \\
\hline T3 & $6.23 \pm 0.01^{\text {cde }}$ & $12.34 \pm 0.39^{\mathrm{a}}$ & $0.73 \pm 0.13^{\mathrm{bc}}$ & $0.49 \pm 0.04^{\mathrm{ab}}$ \\
\hline $\mathrm{T} 4$ & $6.24 \pm 0.01^{\text {cde }}$ & $11.36 \pm 0.49^{\mathrm{bc}}$ & $1.72 \pm 0.05^{\mathrm{a}}$ & $0.53 \pm 0.05^{\mathrm{a}}$ \\
\hline T5 & $6.29 \pm 0.01^{\mathrm{bcd}}$ & $11.27 \pm 0.29^{\mathrm{bcd}}$ & $0.49 \pm 0.20^{\mathrm{cd}}$ & $0.29 \pm 0.01^{\mathrm{e}}$ \\
\hline T6 & $6.32 \pm 0.01^{\mathrm{bc}}$ & $9.80 \pm 0.68^{\mathrm{f}}$ & $0.57 \pm 0.28^{\mathrm{bcd}}$ & $0.53 \pm 0.10^{\mathrm{a}}$ \\
\hline $\mathrm{T} 7$ & $6.50 \pm 0.15^{\mathrm{a}}$ & $11.85 \pm 0.58^{\mathrm{ab}}$ & $0.58 \pm 0.16^{\mathrm{bcd}}$ & $0.38 \pm 0.01^{\mathrm{cd}}$ \\
\hline $\mathrm{T} 8$ & $6.19 \pm 0.01^{\mathrm{de}}$ & $10.09 \pm 0.09^{\mathrm{ef}}$ & $0.70 \pm 0.16^{\mathrm{bc}}$ & $0.33 \pm 0.02^{\mathrm{de}}$ \\
\hline T9 & $6.24 \pm 0.01^{\text {cde }}$ & $10.48 \pm 0.29^{\mathrm{def}}$ & $0.34 \pm 0.04^{\mathrm{d}}$ & $0.33 \pm 0.02^{\mathrm{de}}$ \\
\hline $\mathrm{T} 10$ & $6.22 \pm 0.01^{\text {cde }}$ & $10.38 \pm 0.19^{\mathrm{ef}}$ & $0.46 \pm 0.10^{\text {cd }}$ & $0.34 \pm 0.01^{\mathrm{de}}$ \\
\hline $\mathrm{T} 11$ & $6.14 \pm 0.10^{\mathrm{e}}$ & $9.80 \pm 0.49^{\mathrm{f}}$ & $0.79 \pm 0.17^{\mathrm{b}}$ & $0.41 \pm 0.03^{\mathrm{bcd}}$ \\
\hline $\mathrm{T} 12$ & $6.34 \pm 0.02^{\mathrm{b}}$ & $10.09 \pm 0.29^{\mathrm{ef}}$ & $0.74 \pm 0.09^{\mathrm{bc}}$ & $0.47 \pm 0.03^{\mathrm{ab}}$ \\
\hline
\end{tabular}

\footnotetext{
${ }^{1}$ Treatment compositions are the same as those shown in Table 1.

${ }^{a-e}$ Mean \pm standard deviation with different superscript letters indicating significant differences $(p<0.05)$.
} 
1995; Cofrades et al., 2000).

The shear force values of emulsion-type pork sausages manufactured using a range of component ratios are given in Table 2. Shear force values were found to be higher in treatments containing $3 \mathrm{P}$ fat and $4 \mathrm{P}+20$ water (T3), as well as $3.5 \mathrm{P}$ fat and $4 \mathrm{P}+20$ water (T7), whereas treatments containing $3.5 \mathrm{P}$ fat and $4 \mathrm{P}+15$ water (T6), and $4 \mathrm{P}$ fat and $4 \mathrm{P}+20$ water (T11) showed lower shear force values among the treatments. There were no significant differences among the treatments containing $4 \mathrm{P}$ fat $(\mathrm{p}>0.05)$. On the other hand, Colmenero et al. (1995) reported that products with an increased fat content required a greater penetration force, with similar results being reported previously by other authors (Mayfield et al., 1978; Ahmed et al., 1990; Claus et al., 1990). However, the results of our study demonstrated that a fat level higher than $3.5 \mathrm{P}$ resulted in a decrease in shear force value. We expect that this is due to a reduction in binding capability through the presence of excess fat levels compared to the protein and water contents during emulsion formation.

We also observed that the purge loss was significantly affected by the raw material components (Tables 2 and 5). Treatments containing $3 \mathrm{P}$ fat and $4 \mathrm{P}+25$ water had the highest purge loss compared to the other treatments $(\mathrm{p}<0.05)$, while a higher water content showed a greater purge loss in respective groups classified by fat content (3P, 3.5P, and 4P). In Pearson's correlation test (Table 5), purge loss was also found to negatively correlate with fat content, while a positive correlation was observed with water content $(p<0.05)$. However, no significant link was observed between protein content and purge loss. Youssef and Barbut (2011b) reported that the higher fluid loss was found in the low fat meat emulsion. These results were consistent with the finding of Hughes et al. (1997). Claus et al. (1990) reported that the reason for this observation is likely to be due to the lower water-binding activity in the low fat, high- water treatments being related to their lower ionic strength.

The content of residual nitrite ions was also significantly affected by the ratios of fat and water in emulsion-type pork sausages (Tables 2 and 5). In general, residual nitrite contents of treatments containing $3 \mathrm{P}$ fat were higher compared to those containing $3.5 \mathrm{P}$ and $4 \mathrm{P}$ fat excluding $\mathrm{T} 6$ and $\mathrm{T} 12$, with these results reflecting the different ratios of fat and water used in their production. As previously mentioned, water contents above the maximum level of the respective fat contents (3P, 3.5P, and 4P) resulted in loss of water from the sausage. Therefore, it has been considered that as water is lost, nitrite ions may also be stayed. It is also possible that nitrite ions could be oxidized to nitrate ions, and could subsequently bind to various other meat constituents (Honikel, 2008).

\section{Color}

The data in Table 3 show that the raw material components have a significant effect on the Commission Internationale de l'Eclairage color measurements $\left(\mathrm{L}^{*}, \mathrm{a}^{*}\right.$, $\left.b^{*}\right)$ of emulsion-type pork sausages. We observed that the treatment containing $3.5 \mathrm{P}$ fat and $4 \mathrm{P}+15$ water had the highest $\mathrm{L}^{*}$ value compared to all other treatments $(\mathrm{p}<0.05)$. The $L^{*}$ values of lightness increased with increasing fat content (Table 5), but no significant variations were observed with variation in protein content. The highest redness value $\left(\mathrm{a}^{*}\right)$ compared to the other treatments was observed for treatment 5 (3.5P fat and $4 \mathrm{P}+10$ water). Protein and fat contents displayed a positive correlation with the $a^{*}$ value, whereas water content showed a negative correlation (Table 5). The $\mathrm{p}$ value for $\mathrm{a}^{*}$ was higher for the protein and water components than for the fat components. In addition, the $\mathrm{L}^{*}$ and $\mathrm{a}^{*}$ values reduced significantly with an increase in water content for the groups classified by fat content (3P, 3.5P, and 4P). On the other hand, the $\mathrm{b}^{*}$ values of yellowness showed the opposite trend to the $\mathrm{L}^{*}$ and $\mathrm{a}^{*}$ values, increasing with an increase in water content. Youssef and Barbut (2011a) reported that higher levels of protein and lean meat resulted in a significant increase in redness values in the emulsion meat batter, likely due to a higher myoglobin content. This theory is supported by work by Carballo et al. (1995), where the dilution of myoglobin through reduced protein content in the formulation led to a lower redness value. According to Hughes et al. (1997), it was noted that reducing the fat content resulted in a decrease in both lightness and yellowness, and increased the redness of Frankfurt sausages. In a number of previous studies, it was observed that the color of emulsion-type products was mostly influenced by fat content and added

Table 3. $\mathrm{CIE}^{1}$ color of emulsion-type pork sausages by ratio of raw material components

\begin{tabular}{llll}
\hline Treatment $^{2}$ & \multicolumn{1}{c}{$\mathrm{L}^{*}$} & \multicolumn{1}{c}{$\mathrm{a}^{*}$} & \multicolumn{1}{c}{$\mathrm{b}^{*}$} \\
\hline T1 & $83.00 \pm 0.52^{\mathrm{c}}$ & $3.81 \pm 0.35^{\mathrm{ab}}$ & $10.62 \pm 0.21^{\mathrm{efg}}$ \\
T2 & $82.18 \pm 0.35^{\mathrm{d}}$ & $3.47 \pm 0.08^{\mathrm{bcd}}$ & $11.01 \pm 0.13^{\mathrm{bcd}}$ \\
T3 & $82.02 \pm 0.20^{\mathrm{d}}$ & $3.18 \pm 0.08^{\mathrm{d}}$ & $11.26 \pm 0.07^{\mathrm{abc}}$ \\
T4 & $79.63 \pm 0.32^{\mathrm{e}}$ & $2.77 \pm 0.21^{\mathrm{e}}$ & $11.43 \pm 0.02^{\mathrm{a}}$ \\
T5 & $83.27 \pm 0.02^{\mathrm{bc}}$ & $4.05 \pm 0.15^{\mathrm{a}}$ & $10.44 \pm 0.04^{\mathrm{g}}$ \\
T6 & $84.54 \pm 0.12^{\mathrm{a}}$ & $3.29 \pm 0.10^{\mathrm{cd}}$ & $10.57 \pm 0.16^{\mathrm{fg}}$ \\
T7 & $83.07 \pm 0.11^{\mathrm{c}}$ & $3.56 \pm 0.27^{\mathrm{bcd}}$ & $10.96 \pm 0.27^{\text {cde }}$ \\
T8 & $82.92 \pm 0.78^{\mathrm{c}}$ & $3.21 \pm 0.42^{\text {cd }}$ & $11.15 \pm 0.44^{\mathrm{abcd}}$ \\
T9 & $83.74 \pm 0.12^{\mathrm{b}}$ & $3.62 \pm 0.24^{\mathrm{bc}}$ & $10.59 \pm 0.16^{\mathrm{efg}}$ \\
T10 & $83.25 \pm 0.20^{\text {bc }}$ & $3.43 \pm 0.02^{\text {bcd }}$ & $10.85 \pm 0.29^{\text {def }}$ \\
T11 & $82.02 \pm 0.45^{\mathrm{d}}$ & $3.44 \pm 0.15^{\mathrm{bcd}}$ & $11.20 \pm 0.16^{\mathrm{abcd}}$ \\
T12 & $82.99 \pm 0.37^{\mathrm{c}}$ & $2.66 \pm 0.19^{\mathrm{e}}$ & $11.37 \pm 0.13^{\mathrm{ab}}$ \\
\hline
\end{tabular}

${ }^{1}$ CIE, Commission Internationale de l'Eclairage; $L^{*}=$ lightness, $a^{*}=$ redness, $\mathrm{b}^{*}=$ yellowness.

${ }^{2}$ Treatment compositions are the same as those shown in Table 1.

${ }^{a-g}$ Mean \pm standard deviation with different superscript letters indicating significant differences $(\mathrm{p}<0.05)$. 
Table 4. Texture profile analysis of emulsion-type pork sausages by ratio of raw material components

\begin{tabular}{|c|c|c|c|c|c|c|c|}
\hline Treatment $^{1}$ & $\begin{array}{l}\text { Hardness } \\
(\mathrm{N})\end{array}$ & $\begin{array}{l}\text { Surface hardness } \\
\text { (N) }\end{array}$ & $\begin{array}{c}\text { Cohesiveness } \\
(\%)\end{array}$ & $\begin{array}{l}\text { Springiness } \\
(\mathrm{mm})\end{array}$ & $\begin{array}{l}\text { Gumminess } \\
(\mathrm{N})\end{array}$ & $\begin{array}{l}\text { Chewiness } \\
(\mathrm{N} \times \mathrm{mm})\end{array}$ & $\begin{array}{c}\text { Adhesiveness } \\
(\mathrm{N} \mathrm{s})\end{array}$ \\
\hline $\mathrm{T} 1$ & $2.45 \pm 0.19^{\mathrm{a}}$ & $2.35 \pm 0.29^{\mathrm{ab}}$ & $0.57 \pm 0.08^{\mathrm{bc}}$ & $1.07 \pm 0.09^{\mathrm{bc}}$ & $1.37 \pm 0.29^{\mathrm{bcd}}$ & $1.56 \pm 0.49^{b}$ & $0.98 \pm 0.09^{\mathrm{a}}$ \\
\hline $\mathrm{T} 2$ & $2.54 \pm 0.78^{\mathrm{a}}$ & $2.54 \pm 0.78^{\mathrm{a}}$ & $0.57 \pm 0.15^{\mathrm{bc}}$ & $1.15 \pm 0.22^{\mathrm{bc}}$ & $1.47 \pm 0.49^{\mathrm{b}}$ & $1.76 \pm 0.88^{b}$ & $0.68 \pm 0.09^{\text {cde }}$ \\
\hline $\mathrm{T} 3$ & $1.76 \pm 0.09^{\mathrm{b}}$ & $1.76 \pm 0.09^{\mathrm{c}}$ & $2.21 \pm 0.01^{\mathrm{a}}$ & $3.60 \pm 0.15^{\mathrm{a}}$ & $3.92 \pm 0.19^{\mathrm{a}}$ & $14.11 \pm 1.27^{\mathrm{a}}$ & $0.58 \pm 0.00^{\mathrm{ef}}$ \\
\hline $\mathrm{T} 4$ & $1.37 \pm 0.09^{\mathrm{cd}}$ & $1.37 \pm 0.09^{\mathrm{de}}$ & $0.69 \pm 0.26^{\mathrm{b}}$ & $1.34 \pm 0.40^{\mathrm{b}}$ & $0.98 \pm 0.39^{\text {cde }}$ & $1.37 \pm 0.98^{\mathrm{b}}$ & $0.39 \pm 0.09^{\mathrm{h}}$ \\
\hline $\mathrm{T} 5$ & $2.45 \pm 0.09^{\mathrm{a}}$ & $2.45 \pm 0.09^{\mathrm{a}}$ & $0.56 \pm 0.01^{\mathrm{bc}}$ & $1.01 \pm 0.01^{\mathrm{c}}$ & $1.27 \pm 0.09^{\mathrm{bcd}}$ & $1.27 \pm 0.09^{\mathrm{b}}$ & $0.88 \pm 0.09^{\mathrm{ab}}$ \\
\hline T6 & $1.96 \pm 0.00^{\mathrm{b}}$ & $1.96 \pm 0.00^{\mathrm{bc}}$ & $0.54 \pm 0.13^{\mathrm{bc}}$ & $1.09 \pm 0.16^{\mathrm{bc}}$ & $1.07 \pm 0.29^{\text {bcde }}$ & $1.17 \pm 0.49^{b}$ & $0.58 \pm 0.09^{\mathrm{def}}$ \\
\hline $\mathrm{T} 7$ & $1.96 \pm 0.00^{\mathrm{b}}$ & $1.96 \pm 0.00^{\mathrm{bc}}$ & $0.50 \pm 0.02^{\mathrm{bc}}$ & $1.00 \pm 0.01^{\mathrm{c}}$ & $0.98 \pm 0.00^{\text {bcde }}$ & $0.98 \pm 0.00^{\mathrm{b}}$ & $0.68 \pm 0.00^{\text {cde }}$ \\
\hline $\mathrm{T} 8$ & $1.66 \pm 0.19^{\mathrm{bc}}$ & $1.66 \pm 0.19^{\mathrm{cd}}$ & $0.54 \pm 0.10^{\mathrm{bc}}$ & $1.12 \pm 0.15^{\mathrm{bc}}$ & $0.88 \pm 0.29^{\mathrm{de}}$ & $0.98 \pm 0.49^{\mathrm{b}}$ & $0.49 \pm 0.09^{\mathrm{fgh}}$ \\
\hline T9 & $2.45 \pm 0.09^{\mathrm{a}}$ & $2.45 \pm 0.09^{\mathrm{a}}$ & $0.57 \pm 0.10^{\mathrm{bc}}$ & $1.13 \pm 0.17^{\mathrm{bc}}$ & $1.47 \pm 0.19^{\mathrm{bc}}$ & $1.66 \pm 0.49^{b}$ & $0.78 \pm 0.00^{\mathrm{bc}}$ \\
\hline $\mathrm{T} 10$ & $1.96 \pm 0.00^{\mathrm{b}}$ & $1.96 \pm 0.00^{\mathrm{bc}}$ & $0.56 \pm 0.01^{\mathrm{bc}}$ & $1.06 \pm 0.01^{\mathrm{bc}}$ & $0.78 \pm 0.00^{\text {bcde }}$ & $1.07 \pm 0.09^{\mathrm{b}}$ & $0.68 \pm 0.09^{\mathrm{cd}}$ \\
\hline T11 & $1.66 \pm 0.09^{\mathrm{bc}}$ & $1.66 \pm 0.09^{\mathrm{cd}}$ & $0.48 \pm 0.02^{\mathrm{c}}$ & $1.00 \pm 0.00^{\mathrm{c}}$ & $0.89 \pm 0.09^{\mathrm{e}}$ & $0.68 \pm 0.09^{b}$ & $0.58 \pm 0.09^{\mathrm{gf}}$ \\
\hline $\mathrm{T} 12$ & $1.17 \pm 0.09^{\mathrm{d}}$ & $1.17 \pm 0.09^{\mathrm{e}}$ & $0.53 \pm 0.02^{\mathrm{bc}}$ & $1.09 \pm 0.02^{\mathrm{bc}}$ & $0.68 \pm 0.00^{\mathrm{e}}$ & $0.68 \pm 0.00^{\mathrm{b}}$ & $0.49 \pm 0.09^{\mathrm{gh}}$ \\
\hline
\end{tabular}

${ }^{1}$ Treatment compositions are the same as those shown in Table 1.

${ }^{\mathrm{a}-\mathrm{h}}$ Mean \pm standard deviation with different superscript letters indicating significant differences $(\mathrm{p}<0.05)$.

water (Carballo et al., 1995; Bloukas et al., 1997; Hughes et al., 1997). We also made similar observations, where the redness of the sausage was increased by raising the fat level.

\section{Texture profile analysis}

The texture profile analysis of emulsion-type pork sausages according to treatment number was expressed in Table 4. Significant differences were found in all parameters of texture profile $(p<0.05)$. Compared to other treatments, the highest hardness values were observed for $\mathrm{T} 1$ ( $4 \mathrm{P}+10$ water) and $\mathrm{T} 2(4 \mathrm{P}+15$ water) of the $3 \mathrm{P}$ fat group, $\mathrm{T} 5(4 \mathrm{P}+10$ water $)$ of the $3.5 \mathrm{P}$ fat group, and $\mathrm{T} 9(4 \mathrm{P}+10$ water) of the 4P fat group. We observed that in the three groups classified by fat content (3P, 3.5P, and 4P), the surface hardness, adhesiveness, and hardness values decreased as the water content was increased. The highest values of cohesiveness, springiness, gumminess, and chewiness were observed for treatment 3 ( $3 \mathrm{P}$ fat and $4 \mathrm{P}+20$ water). From these results, we concluded that the raw material ratio of treatment 3 was the most suitable for sausage production. According to study of Choe et al. (2013), emulsion sausages with higher values in cohesiveness, gumminess and chewiness showed significantly superb emulsion stability than those with low values. In the Pearson correlation test (Table 5), protein content displayed a positive correlation with hardness, surface hardness, and adhesiveness values, whereas water displayed a negative correlation with adhesiveness $(\mathrm{p}<0.01)$. Additionally, a positive correlation was observed between fat content and adhesiveness $(\mathrm{p}<0.05)$. According to Banon et al. (2008), an increase in the fat/lean meat ratio also decreased gel strength, leading to lower values of hardness, cohesiveness, gumminess, springiness, and chewiness. This result was likely due to the lack of emulsifying agents from salt-soluble proteins such as myosin, which would result in poorer quality characteristics in the sausages. Similar results were also reported by a number of research groups (Bloukas and Paneras, 1993; Colmenero et al., 1995; Cofrades et al., 2000). In our studies, we also observed that an increase in water content resulted in a decrease in protein content. Hughes et al. (1998) reported that a decrease in fat content significantly reduced cohesiveness and gumminess in Frankfurter sausages. This is in contrast to our result, where we observed that the fat content showed a negative correlation to cohesiveness, springiness, gumminess, and chewiness, although the difference was minimal ( $p>0.05)$. Input of excessive fat content brings an emulsion breaking, due to lack of protein content surrounding fat globules in emulsion formation.

We investigated a number of treatments for the raw materials used in the preparation of emulsion-type pork

Table 5. Pearson's correlation test between raw material components and physicochemical parameters in emulsion-type pork sausages

\begin{tabular}{lccc}
\hline & Protein & Fat & Water \\
\hline pH & -0.1042 & 0.0459 & -0.0178 \\
Shear force & 0.4738 & -0.3359 & 0.2025 \\
Purge loss & -0.3375 & $-0.6899^{*}$ & $0.7194^{*}$ \\
Nitrite & -0.1664 & $-0.5939^{*}$ & $0.5908^{*}$ \\
Lightness & 0.1081 & $0.7338^{*}$ & $-0.7065^{*}$ \\
Redness & $0.7646^{* *}$ & $0.6795^{*}$ & $-0.8073^{* *}$ \\
Yellowness & $-0.7469^{* *}$ & $-0.7614^{* *}$ & $0.8784^{* * *}$ \\
Hardness & $0.8383^{* * *}$ & 0.3138 & -0.4847 \\
S-hardness & $0.8383^{* * *}$ & 0.3138 & -0.4847 \\
Cohesiveness & 0.1331 & -0.4128 & 0.3529 \\
Springiness & 0.0957 & -0.4349 & 0.3820 \\
Gumminess & 0.4586 & -0.2473 & 0.1241 \\
Chewiness & 0.1825 & -0.3511 & 0.2839 \\
Adhesiveness & $0.8332^{* *}$ & $0.5820^{*}$ & $-0.7324^{*}$ \\
\hline
\end{tabular}


sausages, and examined their effects on the physicochemical characteristics of the sausages. All of the treatments investigated showed normal $\mathrm{pH}$ (6.14-4.50), normal shear force ( 9.80 to $12.34 \mathrm{~N} / \mathrm{cm}^{2}$ ), low purge loss, and minimal residual nitrite content $(70 \mathrm{mg} / \mathrm{kg})$ in the emulsion-type pork sausages. We observed that the $\mathrm{pH}$ value was significantly higher in $\mathrm{T} 7(3.5 \mathrm{P}$ fat and $4 \mathrm{P}+20$ water) and T12 (4P fat and $4 \mathrm{P}+25$ water), and that the highest shear force value was recorded for T7 (3.5P fat and $4 \mathrm{P}+20$ water). Changes in fat and water content were found to result in the fluctuation of purge loss and residual nitrite content. Meat color was influenced by variations in all three components. Lightness and redness values were significantly reduced by increasing the water content, while yellowness values increased. Also, it was observed that the both the water and protein contents significantly affected the texture profile of the sausages, where the treatments containing $3 \mathrm{P}$ fat and $4 \mathrm{P}+20$ water had the highest values for cohesiveness, springiness, gumminess, and chewiness. We could therefore conclude that increasing the moisture content and reducing the fat and protein contents resulted in the reduction of the values of a range of physicochemical characteristics.

\section{CONFLICT OF INTEREST}

We certify that there is no conflict of interest with any financial organization regarding the material discussed in the manuscript.

\section{ACKNOWLEDGMENTS}

This work was carried out with the support of the "Cooperative Research Program for Agriculture, Science, \& Technology Development (Project title: Development of Manuals for Manufacturing and Hygienic Management of Meat Products for the Revitalization of Meat and Meat Product Selling Business, Project No. PJ009848)," Rural Development Administration, Republic of Korea. This research was also supported by the Priority Research Centers Program through the National Research Foundation of Korea (NRF), funded by the Ministry of Education (2009-0093813). This Research was supported by the Chung-Ang University Research Grants in 2014.

\section{REFERENCES}

Ahmed, P. O., M. F. Miller, C. E. Lyon, H. M. Vaughters, and J. O. Reagan. 1990. Physical and sensory characteristics of low-fat fresh pork sausage processed with various levels of added water. J. Food Sci. 55:625-628.

Allais, I. 2010. Emulsification In: Handbook of Meat Processing. Wiley-Blackwell, Ames, Iowa, USA. pp. 143-168.

Banon, S., P. Diaz, G. Nieto, M. Castillo, and D. Alvarez. 2008.
Modelling the yield and texture of comminuted pork products using color and temperature. Effect of fat/lean ratio and starch. Meat Sci 80:649-655.

Bloukas, J. G. and E. D. Paneras. 1993. Substituting olive oil for pork backfat affects quality of low-fat frankfurters. J. Food Sci. 58:705-709.

Bloukas, J. G., E. D. Paneras, and S. Papadima. 1997. Effect of carrageenan on processing and quality characteristics of lowfat frankfurters. J. Muscle Foods 8:63-83.

Carballo, J., N. Mota, G. Barreto, and F. J. Colmenero. 1995. Binding properties and colour of bologna sausage made with varying fat levels, protein levels and cooking temperatures. Meat Sci 41:301-313.

Carrapiso, A. I. 2007. Effect of fat content on flavour release from sausages. Food Chem. 103:396-403.

Choe, J.-H., H.-Y. Kim, J.-M. Lee, Y.-J. Kim, and C.-J. Kim. 2013. Quality of frankfurter-type sausages with added pig skin and wheat fiber mixture as fat replacers. Meat Sci. 93:849-854.

Claus, J. R., M. C. Hunt, C. L. Kastner, and D. H. Kropf. 1990. Low-fat, high-added water bologna: Effects of massaging, preblending, and time of addition of water and fat on physical and sensory characteristics. J. Food Sci. 55:338-341.

Cofrades, S., M. A. Guerra, J. Carballo, F. Fernandez-Martin, and F. J. Colmenero. 2000. Plasma protein and soy fiber content effect on bologna sausage properties as influenced by fat level. J. Food Sci. 65:281-287.

Colmenero, F. J., G. Barreto, P. Fernández, and J. Carballo. 1996. Frozen storage of bologna sausages as a function of fat content and of levels of added starch and egg white. Meat Sci. 42:325332.

Colmenero, F. J., G. Barreto, N. Mota, and J. Carballo. 1995. Influence of protein and fat content and cooking temperature on texture and sensory evaluation of bologna sausage. LWT Food Sci. Technol. 28:481-487.

Galluzzo, S. J. and J. M. Regenstein. 1978. Role of chicken breast muscle proteins in meat emulsion formation: Myosin, actin and synthetic actomyosin. J. Food Sci. 43:1761-1765.

Honikel, K.-O. 2008. The use and control of nitrate and nitrite for the processing of meat products. Meat Sci. 78:68-76.

Hughes, E., S. Cofrades, and D. J. Troy. 1997. Effects of fat level, oat fibre and carrageenan on frankfurters formulated with 5, 12 and 30\% fat. Meat Sci. 45:273-281.

Hughes, E., A. M. Mullen, and D. J. Troy. 1998. Effects of fat level, tapioca starch and whey protein on frankfurters formulated with $5 \%$ and $12 \%$ fat. Meat Sci. $48: 169-180$.

Hwang, H. Y. and S. K. Rhee. 2003. Effects of emulsifying stability and product quality of sausages by adding different amount of fat and water. Hankyong National University 35:167-176.

Jin, S. K., I. S. Kim, Y. W. Nam, S. C. Park, S. Y. Choi, H. S. Yang, and Y. J. Choi. 2008. Articles : Comparison of textural properties of crab-flavored sausage with different proportions of chicken meat. Kor. J. Food Sci. Anim. Resour. 28:395-400.

Mayfield, T. L., K. K. Hale, V. N. M. Rao, and I. A. AnguloChacon. 1978. Effects of levels of fat and protein on the stability and viscosity of emulsions prepared from mechanically deboned poultry meat. J. Food Sci. 43:197-201.

Ockerman, H. and L. Basu. 2004. Chemistry and physics of comminuted products: Other ingredients. In: Encyclopedia of 
Meat Sciences (Ed. W. K. E. Jensen). Elsevier, Oxford, UK. pp. SAS. 2012. The SAS program for window. The SAS Institute, Inc. 283-289. Cary, NC, USA.

Pearson, A. M. and T. A. Gillett. 1996. Least cost formulation and preblending of sausage. In: Processed Meats (Ed. A. M. Pearson and T. A. Gillett). Springer, New York, NY, USA. pp. 180-209.

Pietrasik, Z. 1999. Effect of content of protein, fat and modified starch on binding textural characteristics, and colour of comminuted scalded sausages. Meat Sci. 51:17-25.

Pouttu, P. and E. Puolanne. 2004. A procedure to determine the water-binding capacity of meat trimmings for cooked sausage formulation. Meat Sci. 66:329-334.

Puolanne, E. J., M. H. Ruusunen, and J. I. Vainionpaa. 2001. Combined effects of nacl and raw meat ph on water-holding in cooked sausage with and without added phosphate. Meat Sci. $58: 1-7$.

Wang, P., X.-1. Xu, and G.-h. Zhou. 2009. Effects of meat and phosphate level on water-holding capacity and texture of emulsion-type sausage during storage. Agric. Sci. China 8:1475-1481.

Youssef, M. K. and S. Barbut. 2010. Physicochemical effects of the lipid phase and protein level on meat emulsion stability, texture, and microstructure. J. Food Sci. 75:S108-S114.

Youssef, M. K. and S. Barbut. 2011a. Effects of two types of soy protein isolates, native and preheated whey protein isolates on emulsified meat batters prepared at different protein levels. Meat Sci. 87:54-60.

Youssef, M. K. and S. Barbut. 2011b. Fat reduction in comminuted meat products-effects of beef fat, regular and pre-emulsified canola oil. Meat Sci. 87:356-360. 